\title{
A Parallel History? Rethinking the Relationship between Italy and Germany, ca. 1860-1945
}

DOI:

$10.1086 / 687475$

Document Version

Accepted author manuscript

Link to publication record in Manchester Research Explorer

\section{Citation for published version (APA):}

Goeschel, C. (2016). A Parallel History? Rethinking the Relationship between Italy and Germany, ca. 1860-1945. The Journal of Modern History, 88(3), 610-632. https://doi.org/10.1086/687475

\section{Published in:}

The Journal of Modern History

\section{Citing this paper}

Please note that where the full-text provided on Manchester Research Explorer is the Author Accepted Manuscript or Proof version this may differ from the final Published version. If citing, it is advised that you check and use the publisher's definitive version.

\section{General rights}

Copyright and moral rights for the publications made accessible in the Research Explorer are retained by the authors and/or other copyright owners and it is a condition of accessing publications that users recognise and abide by the legal requirements associated with these rights.

\section{Takedown policy}

If you believe that this document breaches copyright please refer to the University of Manchester's Takedown Procedures [http://man.ac.uk/04Y6Bo] or contact uml.scholarlycommunications@manchester.ac.uk providing relevant details, so we can investigate your claim.

\section{OPEN ACCESS}




\title{
Review Article
}

\section{A Parallel History? Rethinking the Relationship between Italy and Germany, ca. 1860-1945*}

\author{
Christian Goeschel \\ University of Manchester
}

In 1901, Paul David Fischer, a former senior German government official, published the second edition of his account of contemporary Italy and the Italians. Fischer, a regular visitor to the peninsula since the creation of the Kingdom of Italy fifty years earlier, prefaced his book with a critical warning. He insisted that he had written his Betrachtungen und Studien über die politischen, wirthschaftlichen und sozialen Zustände Italiens for the many German Italophiles who were

\footnotetext{
* I should like to thank Valerie McGuire, David Laven, Molly Loberg, Lucy Riall, Jan Rüger, and Caterina Sinibaldi for their helpful advice on an early version of this article. The books reviewed here include Arnaldo Di Benedetto, Fra Germania e Italia: Studi e flashes letterari (Florence: Olschki, 2008), pp. vii+195, €24.00; Mauro Fosco Bertola, Die List der Vergangenheit: Musikwissenschaft, Rundfunk und Deutschlandbezug in Italien, 18901945 (Vienna: Böhlau, 2014),pp. 352,€49.00; Manuel Borutta, Antikatholizismus: Deutschland und Italien im Zeitalter der europäischen Kulturkämpfe (Göttingen: Vandenhoeck \& Ruprecht, 2010), pp. 488, €69.99; Gabriele B. Clemens, Malte König, and Marco Meriggi, eds., Hochkultur als Herrschaftselement: Italienischer und deutscher Adel im langen 19. Jahrhundert (Berlin: De Gruyter, 2011), pp. vi+340, €94.95; Gustavo Corni and Christof Dipper, eds., Italiener in Deutschland im 19. und 20. Jahrhundert: Kontakte, Wahrnehmungen, Einflüsse (Berlin: Duncker \& Humblot, 2012), pp. 580, €98.00; Christof Dipper, ed., Deutschland und Italien 1860-1960 (Munich: Oldenbourg, 2006), pp. viii+284, €49.80; Filippo Focardi, Il cattivo tedesco e il bravo italiano: La rimozione delle colpe della seconda guerra mondiale (Rome/Bari: Laterza, 2013), pp. xix +288, €24.00; Carlo Gentile, Wehrmacht und Waffen-SS im Partisanenkrieg: Italien, 1943-1945 (Paderborn: Schöningh, 2012), pp. 466, €44.90; Lutz Klinkhammer, Amedeo Osti Guerazzi, and Thomas Schlemmer, eds., Die "Achse” im Krieg (Paderborn: Schöningh, 2010), pp. 540, €48.90; Gian Enrico Rusconi, Cavour e Bismarck: Due leader fra liberalismo e cesarismo (Bologna: Il Mulino, 2010), pp. 212, €15.00; Gian Enrico Rusconi, Deutschland-Italien. ItalienDeutschland: Geschichte einer schwierigen Beziehung von Bismarck zu Berlusconi, trans. Antje Peter (Paderborn: Schöningh, 2006), pp. xii+410, €21.90; Gian Enrico Rusconi and Hans Woller, eds., Parallele Geschichte? Italien und Deutschland, 1945-2000 (Berlin: Duncker \& Humblot, 2006), pp. 576, €118.00; Wolfgang Schieder, Mythos Mussolini: Deutsche in Audienz beim Duce (Munich: Oldenbourg, 2013), pp. 404, €39.80; Simonetta Soldani, ed., Enzo Collotti e l'Europa del novecento (Florence: Firenze University Press, 2011), pp. ix $+270, € 15.90$.
}

The Journal of Modern History 88 (September 2016): 610-632 (C) 2016 by The University of Chicago. 0022-2801/2016/8803-0004\$10.00 All rights reserved. 
interested not just in the "history, the artistic treasures and the natural beauty of Hesperia" but also in contemporary Italy. Unlike many other travel writers, Fischer did not write off Italy as a backward place but rather portrayed it as a forward-looking nation and a great power, despite all the obstacles in the way of creating a unified nation-state. For Fischer, who was writing when Italy and Germany were members of the Triple Alliance with Austria-Hungary, it was clear that the two nations shared a parallel history, having suffered too long from the lack of national unification. Yet Italy had endured even more than Germany under foreign occupation, for Italy had been ruled for centuries by foreign powers, while Germany only had to face French occupation during the wars of the French Revolution and, of course, under Napoleon. ${ }^{1}$

A more profound articulation of the concept of Italy's and Germany's parallel histories is Benedetto Croce's influential Storia d'Italia dal 1871 al 1915. Croce, the celebrated philosopher, historian, and chief intellectual of the bygone Liberal Italy and senator for life, was one of the few independent thinkers who could articulate his ideas in Fascist Italy more or less openly. In this book, published in 1928, ten years after the end of the First World War and six years after Benito Mussolini's appointment as prime minister heralded an increasingly repressive regime, Croce looked back at the period between the completion of Italy's unification, with the establishment of Rome as the national capital in 1871, and the country's entry into the First World War in 1915. He declared that "Italy, in these days ... played the part of a teacher in the sphere of politics, and when the Prussian envoy, in October 1860, presented the protests of his Government against Italian annexations, Cavour was able to answer that Prussia would one day be grateful to Piedmont for the example which she had given of the way in which German unity could be effected." Croce's praise for Piedmont's annexations of territories in northern and central Italy and his emphasis on Italian unification as a model for that of Germany highlighted Italy's role as the political laboratory of Europe. $^{3}$

In the interwar period, some German intellectuals articulated similar views. The right-wing Moeller van den Bruck who coined the phrase the "Third Reich"

${ }^{1}$ P. D. Fischer, Italien und die Italiener: Betrachtungen und Studien über die politischen, wirthschaftlichen und sozialen Zustände Italiens, 2nd ed. (Berlin, 1901), 1, 20; on travel writing, see John Pemble, The Mediterranean Passion: Victorians and Edwardians in the South (Oxford, 1987), 167-240; on German views, see Arnold Esch and Jens Petersen, eds., Deutsches Ottocento: Die deutsche Wahrnehmung Italiens im Risorgimento (Tübingen, 2000).

${ }^{2}$ Benedetto Croce, A History of Italy 1871-1915, trans. Cecilia M. Ady (Oxford, 1929), 27; on Croce, see Denis Mack Smith, "Benedetto Croce: History and Politics," Journal of Contemporarv Historv 8 (1973): 41-61, 56, and Fabio Fernando Rizi, Benedetto Croce and Italian Fascism (Toronto, 2003).

${ }^{3}$ On Italy's pioneering role in European politics, see Lucy Riall, "Progress and Compromise in Liberal Italy," Historical Journal 38 (1995): 205-13, 205. 


\section{Goeschel}

provided one of the most emblematic manifestations of the view that Italy served as a political role model for Germany. In an essay published in November 1922, days after Mussolini's appointment as prime minister, Moeller van den Bruck declared: "Italia docet" (Italy teaches). He praised Fascism as the logical continuation of the Risorgimento and recommended Mussolini's ultranationalist movement with imperialist aspirations to Germans as a viable alternative to the purported Bolshevik threat. Nevertheless, Bruck rescinded his ideas months later and denounced Italian Fascism as reactionary-perhaps a reflection of the ambivalent views most Germans had of Italy. ${ }^{4}$ Indeed, Bruck's views stand in a long tradition of ambivalent German attitudes toward Italy, which were characterized by a mix of admiration for Italy's artistic heritage and its beautiful landscape, on the one hand, and hostility toward the Italians themselves, on the other. Goethe articulated this position perhaps most forcefully in his Italienische Reise, his celebrated account of his journey to Italy in the late 1780s highlighting some of the typical perceptions of northern Europeans embarking upon the Grand Tour. ${ }^{5}$

There indeed seem to be many significant parallels in Italian and German history. Furthermore, the relationship between Italy and Germany was one of the most significant bilateral political, cultural, and economic relationships in modern European history. The history of both countries is closely intertwined, marked by conflict, mutual admiration, envy, and open warfare, including the conflict between the Roman and Germanic Empires, the numerous wars between the Holy Roman Empire and the papacy in the Middle Ages over the political domination of the Italian peninsula, the Napoleonic wars, the rise of nationalism, and above all the political unifications of both countries in the late nineteenth century. This process of nation-building coincided with a push for empire-building. Joined in the Triple Alliance with Austria-Hungary from 1882 until Italy's exit in 1915, the two countries were at war with each other from 1916 until 1918. Italy emerged as a victor of the First World War, although there was a widespread perception of a mutilated victory (vittoria mutilata) because Italy's territorial demands were not fulfilled at the Paris peace conference. Germany experienced defeat, revolution, and, like Italy, a widely perceived sense of national humiliation. Almost exactly four years after the end of the war, Benito Mussolini, leader of the Fascists, was appointed prime minister by King Victor Emanuel III, having attained power through a twofold strategy combining political violence with semilegal political

\footnotetext{
${ }^{4}$ Moeller van den Bruck, "Italia docet," in Das Recht der jungen Völker: Sammlung politischer Aufsätze, ed. Hans Schwarz (Berlin, 1932), 123-25; on context, see Stefan Breuer, "Moeller van den Bruck und Italien," Archiv für Kulturgeschichte 84 (2002): 413 $38,436-37$.

${ }^{5}$ For an English edition, see Johann Wolfgang von Goethe, Italian Journey, trans. Robert R. Heitner, ed. Thomas P. Saine and Jeffrey L. Sammons (Princeton, NJ, 1994); on context, see Norbert Miller, Der Wanderer: Goethe in Italien (Munich, 2002).
} 
activity. Eleven years later, the Nazi leader Adolf Hitler came to power in Germany, following a similar strategy that integrated political violence with quasi-legal activity. ${ }^{6}$ Over the course of the 1930s, after the consolidation of the Fascist and Nazi regimes, both countries began to push for territorial expansion. A new ItaloGerman alliance gradually emerged. Even though that alliance was concluded in May 1939 as the Pact of Steel, Italy did not join Germany in the Second World War until June 1940: the country, exhausted from the conquest of Abyssinia and its involvement in the Spanish Civil War, was not ready to fight a war in the autumn of September 1939. This decision did not raise the Italians' reputation in Germany. From June 1940 until September 1943, both countries, as allies, fought the most deadly war the world had ever seen.

Despite all of these common political and historical patterns, historians have long hesitated to develop a meaningful transnational and comparative historiography of Italy and Germany because of an existing historiography that, until the rise of comparative history in the 1970s and transnational history in the 1990s, remained all too often isolated in national paradigms. Another obstacle stands in the way of writing the history of Italy and Germany under Fascism as well: ever since the emergence of the Holocaust as the focal point of the Third Reich's historiography, many historians of Nazi Germany have avoided the study of comparisons and transfers with other repressive regimes of the twentieth century, citing the "uniqueness" of the Third Reich and the Nazi extermination of European Jewry. ${ }^{7}$ As a result, with few exceptions, the historiography of Nazi Germany is becoming increasingly isolated from modern European history. ${ }^{8}$ In Italian historiography, too, known for its heavy focus on national history and its frequent shunning of comparative history and transfer history (an approach that examines transfers of ideas and people between countries), there is relatively little space for an exploration of Italo-German history. Apart from this frequent selfisolation of Italian history, many historians of modern Europe, especially in the

\footnotetext{
${ }^{6}$ Hans-Ulrich Thamer, "Der Marsch auf Rom-ein Modell für die nationalsozialistische Machtergreifung," in Die nationalsozialistische Machtergreifung, ed. Wolfgang Michalka (Paderborn, 1984), 245-60; for a similar argument, see Wolfgang Schieder, "Das italienische Experiment: Der Faschismus als Vorbild in der Weimarer Republik," Historische Zeitschrift 262 (1996): 73-125; see also the recent, largely descriptive study by Matthias Damm, Die Rezeption des italienischen Faschismus in der Weimarer Republik (BadenBaden, 2013).

${ }^{7}$ For a balanced assessment, see Ian Kershaw, "Hitler and the Uniqueness of Nazism," Journal of Contemporarv Historv 39 (2004): 239-54.

${ }^{8}$ See Ian Kershaw and Moshe Lewin, eds., Stalinism and Nazism: Dictatorships in Comparison (Cambridge, 1997); Michael Geyer and Sheila Fitzpatrick, eds., Beyond Totalitarianism: Stalinism and Nazism Compared (Cambridge, 2009); Kiran Klaus Patel, "Der Nationalsozialismus in transnationaler Perspektive," Blätter für deutsche und internationale Politik 49 (2004): 1123-34.
} 
English-speaking world, see Italy as a marginal country, a view influenced by centuries-old patronizing stereotypes, as Silvana Patriarca has recently argued. ${ }^{9}$ These national stereotypes themselves have had a powerful impact on the memory and historiography of this relationship, as I will argue.

Apart from extensive work on comparative Fascism that emerged in the 1960s, when many historians saw Nazism as a manifestation of Fascism, relatively few historians have attempted to provide a longer and deeper perspective on the relationship between Italy and Germany. ${ }^{10}$ And despite the similarities of their parallel histories, few English-speaking historians since the end of the Second World War, with a handful of exceptions - most notably Tim Mason and MacGregor Knox-have explored them. ${ }^{11}$

A relatively small group of Italian and above all German historians has been working on Italo-German relations since the 1970s, reflecting the rise of comparative history and, since the 1990s, transnational history. These historians examine political relations, mutual perceptions, and, more recently, transfers of people and concepts from one country to another. Unfortunately, because of language issues, much of this work remains inaccessible to English-language readers. Their work is diverse, and it is sometimes difficult to discern common patterns. In this article, I identify the most significant trends in recent work in this field without trying to create a coherence where it does not exist. The work under review here presents three significant and interrelated historiographical problems. First, I address work on the history of national stereotypes in Italy and Germany. Second, I examine the ongoing debate on the significance of the nineteenth century for the failure of liberal democracy and the rise of Fascism in Italy and Germany. And third, I review recent work on Italy and Germany in the 1930s and 1940s - a core theme of research, given the centrality of the Second World War in European history and memory. All in all, I reflect upon the problems of an integrative and synthetic history of Italy and Germany in both the nineteenth and the twentieth centuries. I argue that a closer study of this relationship, employing both comparative and transnational approaches, allows us to revise our interpretation of the significance of the relationship of Italy and Germany in modern European history more generally.

${ }^{9}$ Silvana Patriarca, Italian Vices: Nation and Character from the Risorgimento to the Republic (Cambridge, 2010).

${ }^{10}$ Work includes Ernst Nolte, Der Faschismus in seiner Epoche: Action françaiseitalienischer Faschismus-Nationalsozialismus (Munich, 1963); Wolfgang Schieder, ed., Faschismus als soziale Bewegung (Hamburg, 1976); Stanley Payne, A History of Fascism, 1914-1945 (London, 1995); Robert O. Paxton, The Anatomy of Fascism (New York, 2004).

${ }^{11}$ MacGregor Knox, Common Destiny Dictatorship, Foreign Policy, and War in Fascist Italy and Nazi Germany (Cambridge, 2000), and Knox, To the Threshold of Power 1922/33, vol. 1, Origins and Dynamics of the Fascist and National Socialist Dictatorships (Cambridge, 2007); Tim Mason, "Whatever Happened to 'Fascism'?" in Nazism, Fascism and the Working Class, ed. Jane Caplan (Cambridge, 1995), 323-31. 
As one of the few general introductions to the field, a good starting point for an investigation of Italo-German relations in the nineteenth and twentieth centuries is a recent book by Gian Enrico Rusconi, a political scientist and long-time proponent of Italo-German history. Rusconi provides a solid account of the complex history of Italy and Germany "from Bismarck to Berlusconi." ${ }^{12}$ Rusconi's book, first published in Italian in 2003 and translated into German in 2006, is a largely straightforward narrative, interspersed with the occasional colorful quotation from published primary material. A particular strength of Rusconi's book is the exploration of German and Italian stereotypes of one another's nations. For instance, Rusconi mentions the oft-cited German perception of Italians as unreliable and the frequent Italian view of Germans as arrogant and pompous. For Rusconi, these stereotypes did not emerge from nowhere: they are closely related to the history of Italo-German relations and were reinforced during the First World War. As we have seen, Italy, although allied with Germany and AustriaHungary, initially remained neutral and changed sides in 1915. Later events in Italo-German history, such as Mussolini's refusal to enter the Second World War on Germany's side in September 1939, helped reinforce these stereotypes. These perceptions had dramatic consequences for the treatment of the masses of Italian soldiers who found themselves in German-occupied territories after the purported betrayal of Marshal Badoglio, who had been appointed by the king to succeed Mussolini as prime minister: on September 8, 1943, Badoglio announced an armistice with the Allies that was soon followed by a declaration of war on Germany (3-18, 328-30).

Such stereotypes and images have also been the focus of other recent research. In a book of essays dedicated to literary figures traversing Italy and Germany in the eighteenth and nineteenth centuries, the literary scholar Arnaldo Di Benedetto emphasizes the significance of mutual perceptions in Italo-German relations. German views of Italians range from the romantic fascination for the ruins of ancient Rome to the belittling of the disloyal, unreliable, and fraudulent Italian. Among Italians, respect for the hard-working and efficient German coexists with the dismissal of the uncivilized German, in the guise either of the Nazi soldier or, more recently, of the inappropriately dressed tourist hordes on the Adriatic coast. A recent essay collection edited by Gustavo Corni and Christof Dipper explores the ambiguity of Italians' experiences of, influences on, and perceptions of Germany in the nineteenth and twentieth centuries. The essays discern a significant Italian presence in politics, the arts, gastronomy, economy, labor migration, and academia in Germany, offering a well-researched survey on the depth and variety of contacts among Germans and Italians.

${ }^{12}$ For the Italian edition, see Gian Enrico Rusconi, Germania, Italia, Europa: Dallo stato di potenza alla potenza civile (Turin, 2003). 
In fact, the study of national stereotypes and perceptions of another group necessitates a closer analysis of how national stereotypes were constructed and what political significance, if any, they had. In the 1960s, amidst the climate of reconciliation between the Western combatants and Germany, German-based scholars like Hugo Dyserinck, building on earlier work by French comparatists, came up with the concept of "imagology" to study changing national perceptions and to analyze the importance of the construction and deconstruction of national images. This is a fruitful concept applied to the history of Italo-German relations, as it has the potential to reveal the nexus between national prejudices and politics. $^{13}$

For some years, the literature on German perceptions of Italy in the nineteenth and twentieth centuries has been growing, ranging from studies on political perceptions of Italy in the first half of the nineteenth century to German reactions toward the rise of Fascism in Italy. ${ }^{14}$ The literary scholar Klaus Heitmann, another proponent of imagology, has been tirelessly cataloguing the dynamics of Italian imaginations of Germany from the Roman period until the twentieth century in what amounts to an encyclopedic project; volumes have been published to date up until the Italian entry into the First World War. ${ }^{15}$

These stereotypes, images, and perceptions are not just relevant to interpretations of literary culture: they also have a powerful political legacy. Jens Petersen, one of the pioneers of Italo-German history and author of an important 1973 monograph on the origins of the Axis alliance, ${ }^{16}$ explores the political significance of these stereotypes in his informative contribution to an essay collection edited by Gian Enrico Rusconi and Hans Woller on aspects of Italo-German history between 1945 and 2000, first published in Italian in 2005 and recently translated into German. ${ }^{17}$ Petersen shows that the image of the arrogant, all-too-powerful German still resonates in Italy and is used by politicians to great political effect (Petersen in Rusconi and Woller, 55-69).

As examples from the more recent history of Italo-German relations reveal, anti-German prejudices are still part of the Italian political repertoire. In 2003, for

${ }^{13}$ Hugo Dyserinck, “Zum Problem der 'images' und 'mirages' und ihrer Untersuchung im Rahmen der Vergleichenden Literaturwissenschaft," Arcadia 1 (1966): 107-20; for a more recent take, see Manfred Beller and Joep Leersen, eds., Imagology: The Cultural Construction and Literary Representation of National Characters: A Critical Survey (Amsterdam, 2007).

${ }^{14}$ See, e.g., Wolfgang Altgeld, Das politische Italienbild der Deutschen zwischen Aufklärung und europäischer Revolution von 1848 (Tübingen, 1984); Wolfgang Schieder, Faschistische Diktaturen: Studien zu Italien und Deutschland (Göttingen, 2008).

${ }^{15}$ Klaus Heitmann, Das italienische Deutschlandbild in seiner Geschichte, 3 vols. so far (Heidelberg, 2008-12); for his method, see ibid., 1:13-15.

${ }_{16}$ Jens Petersen, Hitler-Mussolini: Die Entstehung der Achse Berlin-Rom 1933-1936 (Tübingen, 1973).

${ }^{17}$ For the Italian edition, see Gian Enrico Rusconi and Hans Woller, eds., Italia e Germania 1945-2000: La costruzione dell'Europa (Bologna, 2005). 
instance, the media tycoon and then prime minister Silvio Berlusconi told Martin Schulz, deputy leader of the Socialist group in the European Parliament, that he would be perfect for casting as a concentration-camp commandant in a film. ${ }^{18}$ But not only the Italian Right uses these stereotypes. In 2012, amidst the European sovereign debt crisis, the German government refused to soften the stability rules for the euro currency. This policy prompted Eugenio Scalfari, founding editor of the left-liberal La Repubblica newspaper, to declare in an interview that Germany was culpable for "two world wars and a genocide." The Germans ought to be careful "not to commit yet another great wrong" by letting the common European currency fail. Scalfari made no mention whatsoever of the fact that Fascist Italy and Nazi Germany had been allies in the Axis alliance and had fought the Second World War alongside each other from June 1940 until September 1943 (or until April 1945, if one considers Mussolini's Italian Social Republic, which was allied with the Third Reich) ${ }^{19}$ This fateful collaboration has recently been explored in detail from a political and military perspective in an essay collection edited by Lutz Klinkhammer, Amedeo Osti Guerrazzi, and Thomas Schlemmer (Klinkhammer, Osti Guerrazzi, and Schlemmer, 2010).

Scalfari's effectively anti-German statement reflects a powerful Italian postwar discourse. The image of the evil German and the good Italian became powerful in Italy during the Second World War, if not before. An intelligent analysis of how this powerful stereotype developed in this period is Filippo Focardi's 2013 study Il cattivo tedesco e il bravo italiano. Focardi, author of an influential 1996 article on the same topic, claims that the notion of the evil German and good Italian emerged across the broad Italian political spectrum in the wake of the toppling of Mussolini by the Fascist Grand Council and the subsequent Italian armistice with the Allies. ${ }^{20}$ While he does not explicitly engage with the imagology of the longterm history of these national stereotypes, Focardi argues, mainly based on newspapers, pamphlets, and parliamentary debates, that these popular stereotypes have long impeded a serious exploration of the comparative history of Fascist Italy and Nazi Germany (xi).

Italian elites were keen to distance Italy from any association with its former Axis ally. One of the intellectual founding fathers of this discourse of the "good Italian" and the "evil German" was Benedetto Croce. In late 1943, fifteen years after the publication of his remarks on Italy and Germany in his Storia d'Italia, quoted above, Croce evaluated Italo-German relations in an essay entitled "Confessions of an Italian 'Germanophile.'" Croce wrote this essay in Sorrento near

${ }^{18}$ See Spiegel, online, July 2, 2003, http://www.spiegel.de/politik/ausland/berlusconis -eklat-im-europaparlament-ich-schlage-sie-fuer-die-rolle-des-lagerfuehrers-vor-a-255508 .html.

${ }^{19}$ Cited in Birgit Schönau's interview with Eugenio Scalfari, Die Zeit, March 21, 2012.

${ }^{20}$ Filippo Focardi, “'Bravo italiano' e 'cattivo tedesco': Riflessioni sulla genesi di due immagini incrociate," Storia e Memoria 5 (1996): 55-83. 


\section{Goeschel}

Naples after the Allied invasion. His essay was part of a booklet on Germany and Europe, published in Italy in 1944. The philosopher, keen on absolving the Italians from atrocities during the Second World War and above all from the Axis alliance with Nazi Germany, insisted:

There was, for that matter, a deep and intimate difference between Nazism and Fascism, because the first was a terrible crisis which had been brooding in the history of Germany through centuries, and the second was a superfetation foreign to the history of Italy through the centuries and repugnant to the recent and glorious Italian history of the nineteenth century; the first had both a tragic and diabolical aspect, and the second, even in the midst of the crimes it committed, in the midst of the destruction and the ruins, kept an invincibly clownlike aspect, as anybody could see at first glance by contrasting the appearances of the two chiefs. ${ }^{21}$

Thus, for Croce, who famously saw Fascism as a mere parenthesis to Italian history, Nazism was deeply rooted in German history. This view, coupled with the powerful postwar myth of the resistenza, soon became an alibi for the millions of ordinary Italians who had been involved in one way or another with the Fascist regime over the twenty-one years of Mussolini's rule, including those complicit in war crimes perpetrated by Italians, above all during the Abyssinian campaign and during Italian operations in the Balkans during the Second World War. A typical Italian trope was to blame Mussolini for entering into the Axis alliance with Germany, a convenient strategy to downplay the responsibility of Italians complicit in the Fascist regime and the making of the Axis alliance with Germany (Focardi, 77-106, 179-93). In this context, Italians could point to German war crimes in Nazi-occupied Italy, meted out against partisans and civilians in northern and central Italy in the wake of the effective German occupation of the nominally independent Italian Social Republic. Here was a Nazi satellite state, formally run by Mussolini, restored to office in late September 1943 by Hitler, but in reality controlled by various German institutions, competing for power and therefore leading to radical and often brutal policies. ${ }^{22} \mathrm{~A}$ civil war soon ensued between supporters of the Salò Republic, complicit with the Holocaust, and the partisans who were, in reality, not as numerous as the postwar myth of the resistenza implied. ${ }^{23}$

${ }^{21}$ Benedetto Croce, Germany and Europe: A Spiritual Dissension, trans. Vincent Sheehan (New York, 1944), 41; for the same passage in Italian, see Benedetto Croce, Il dissidio spirituale della Germania con l'Europa (Bari, 1944), 21; on Croce during the final stages of war, see Rizi, Benedetto Croce and Italian Fascism, 237-45; see also Patriarca, Italian Vices, 193-97.

${ }^{22}$ The standard work is Lutz Klinkhammer, Zwischen Bündnis und Besatzung: Das nationalsozialistische Deutschland und die Republik von Salò 1943-1945 (Tübingen, 1993).

${ }^{23}$ On the civil war, see Claudio Pavone, Una guerra civile: Saggio storico sulla moralità della resistenza (Turin, 1991); for a recent study of Italian memory, see John Foot, Italv's Divided Memorv (Basingstoke, 2009). 
Not only members of the resistenza but also civilians were brutally killed by the Germans. Some of the most notorious German massacres took place at Marzabotto and Sant'Anna di Stazzema. SS units, alongside the regular German army, were responsible for these war crimes. The participation of the Waffen-SS is the subject of a well-researched monograph by Carlo Gentile that documents the extent of German war crimes with chilling detail. More than 70,000 people were killed in the partisan war between 1943 and 1945, including 10,000 civilians, although precise numbers are difficult to calculate (Gentile, 14-15). ${ }^{24}$

National stereotypes, politics, and postwar memories of Italo-German relations were all intricately linked with one another. Until the end of the Cold War, with Italy and West Germany allied in NATO, war-crimes trials of many perpetrators were effectively blocked. For the West German authorities, there was no incentive to prosecute the suspects, while the Italian authorities were similarly reluctant to open proceedings, as doing so would have opened calls for the prosecution of Italian war criminals. ${ }^{25}$ This suppression of German war crimes in Italy allowed German veterans of the Italian front to deny these crimes with impunity, as Lutz Klinkhammer shows in an essay about the close nexus between Cold War politics and the memory of the war (Klinkhammer in Rusconi and Woller, 89-106).

In the Italian memory of the Second World War, the appalling, often racist treatment of Italian workers in the Third Reich at war and of the so-called Italian military internees, Italian soldiers who refused to fight for Mussolini's Italian Social Republic and were thus denied the status of prisoners of war in Nazi Germany, also helped cement the view of the "good Italian" versus the "evil German." A commission of Italian and German historians, appointed by their governments, has recently investigated this sensitive subject, concluding, perhaps unsurprisingly, that more research is necessary. Needless to say, the notion of the good-natured Italians, incapable of brutality (italiani, brava gente), is part of a wider discourse, with a long historical trajectory, of what constitutes the Italian national character. ${ }^{26}$ Through an implicit comparison of the "soft" Fascist regime

\footnotetext{
${ }^{24}$ Among the many studies of German war crimes in Italy, see Joachim Staron, Fosse Ardeatine und Marzabotto. Deutsche Kriegsverbrechen und Resistenza: Geschichte und nationale Mythenbildung in Deutschland und Italien (1944-1999) (Paderborn, 2002), and Gerhard Schreiber, Deutsche Kriegsverbrechen in Italien: Täter, Opfer, Strafverfolgung (Munich, 1996); Paolo Pezzino, Memory and Massacre: Revisiting Sant'Anna di Stazzema, trans. Noor Giovanni Mazhar (New York, 2012).

${ }^{25}$ See also Filippo Focardi and Lutz Klinkhammer, "The Question of Fascist Italy's War Crimes: The Construction of a Self-Acquitting Myth (1943-1948)," Journal of Modern Italian Studies 9 (2004): 330-48.

26 "Bericht der von den Außenministern der Bundesrepublik Deutschland und Republik Italien am 28.3.2009 eingesetzten Deutsch-Italienischen Historikerkommission," July 2012, available at http://www.auswaertiges-amt.de/cae/servlet/contentblob/633874/publica tionFile/175264/121219-DeuItalHistorikerkommission-Bericht.pdf; on the notion of the
} 
in Italy and the brutal Nazi dictatorship that was responsible for the Holocaust, Italian elites, including historians - above all Renzo De Felice, the indefatigable author of the standard biography of Mussolini - reinforced the view of the "good Italian" and the "brutal German." In two interviews in the late 1980s, De Felice flatly denied significant parallels between Fascist Italy and Nazi Germany. The famous historian insisted that Italy had nothing to do with the Holocaust, effectively whitewashing Italy of any association with war crimes and portraying Italy and the Italians as victims of the war (Focardi in Rusconi and Woller, 107-39). ${ }^{27}$ Focardi shows that the Allied decision not to put Italian war criminals before an international military tribunal similar to the Nuremberg or Tokyo trials — strongly motivated by the strategic desirability of keeping Italy on their side - soon helped to bring about a general amnesia about Italy's Fascist past (Focardi, 107-51). ${ }^{28}$

Undoubtedly, Focardi's 2013 book would have been even stronger if he had included a more systematic discussion of the longer trajectory of Italian stereotypical views of the Germans - part and parcel, one could argue, of Italian national identity. These stereotypes predate the Second World War and go back to at least the First World War, as Enzo Collotti, perhaps Italy's leading historian of modern Germany and the recipient of a recent Festschrift edited by Simonetta Soldani, shows in a kaleidoscopic 1997 essay, part of a project of the Italian lieux de memoire. Nevertheless, despite this critique, Focardi successfully shows how political interests shaped national stereotypes and public memory and, indeed, the historiography of Italo-German relations in the 1930s and 1940s. ${ }^{29}$

\section{II}

The politically motivated Italian postwar juxtaposition of the "evil German" with the "good Italian" effectively aimed to dismantle the notion of Italy's and Germany's parallel histories. According to Croce, quoted above, Nazism was deeply rooted in German history. Thus, the stereotype of the "evil German" reflected one of the most enduring interpretations of German history, namely, the Sonderweg.

Italians as "good people," see Patriarca, Italian Vices, 188-213; for a dissection of the notion of "italiani, brava gente," see Angelo Del Boca, Italiani, brava gente? Un mito duro a morire (Vicenza, 2005).

${ }^{27}$ De Felice's claims are reprinted in Jader Jacobelli, ed., Il fascismo e gli storici oggi (Rome, 1988), 3-6, 7-11; for a good introduction to the debates about De Felice's oeuvre, see Denis Mack Smith, "Mussolini: Reservations about Renzo De Felice's Biography," Modern Italy 5 (2000): 193-210.

${ }_{28}$ See also Michele Battini, The Missing Italian Nuremberg: Cultural Amnesia and Postwar Politics (Basingstoke, 2007).

${ }^{29}$ Enzo Collotti, "I tedeschi," in I luoghi della memoria: Personaggi e date dell' Italia unita, ed. Mario Isnenghi, 3 vols. (Bari/Rome, 1997), 3:65-86; for an in-depth account, see Heitmann, Das italienische Deutschlandbild, vols. 1-3. 
According to this view, Germany's route to modernity over the course of the nineteenth century was fundamentally different from that of other countries, most notably France and Britain, where the bourgeoisie reached political power through a course of revolutions. In Germany, on the other hand, feudal elites, the Junker, remained in charge of politics, so economic modernization was not paralleled by political modernization — a fateful development that, according to the Sonderweg view, made democracy unsustainable in Germany and eventually explained the rise of the Nazis. ${ }^{30}$ Croce too believed that Germany's special path to modernity explained the coming of the Third Reich. An English translation of Croce's 1944 book was published in the same year in the United States. His remarks on the strange character of the Germans and the benign character of the Italians resonated in the United States during the Allied campaign in Italy. A lengthy critical review by Adrienne Koch, an American historian from the University of Maryland, soon appeared in the New York Times. Decades before the British historians Geoff Eley and David Blackbourn would offer a rigorous and analytical demolition of the Sonderweg hypothesis, Koch diagnosed a fundamental problem in Croce's interpretation. She plausibly argued that Germany was just as far apart from the wider trajectory of European history, culture, and politics as, say, Britain. But Koch went even further when she accused Croce of succumbing to simplistic national stereotypes of the "German mind," an interpretation inadequate for explaining Nazism's coming to power and Germany's causing the Second World War. $^{31}$

A similarly powerful counterpoint to the German Sonderweg thesis exists in Italy, where the Marxist Antonio Gramsci, imprisoned under Fascism, interpreted the Risorgimento as a "passive," failed bourgeois revolution. Furthermore, he sharply criticized Croce's adulation of Liberal elites for their role in bringing about the unification of Italy in the nineteenth century. Gramsci saw the seeds of Fascism in the hegemony of those elites who controlled the Italian state to serve their class interests as industrialists or landowners in the south. Ferocious historiographical and political debates about the failure of liberal democracy and the rise of Fascism thus exist in both Italy and Germany, two countries that saw late national unification, the belated emergence of empires, and the coming to

${ }^{30}$ For a robust defense of the Sonderweg, see Jürgen Kocka, "German History before Hitler: The Debate about the German Sonderweg," Journal of Contemporarv Historv 23 (1988): 3-16.

${ }^{31}$ Adrienne Koch, "Croce and the Germans," New York Times, July 30, 1944; Geoff Eley and David Blackbourn, The Peculiarities of German History: Bourgeois Society and Politics in Nineteenth-Century Germany (Oxford, 1984); see also the more recent work on the Sonderweg debate, especially H. Glenn Penny, "The Fate of the Nineteenth Century in German Historiography," Journal of Modern Historv 80 (2008): 81-108; Helmut Walser Smith, "When the Sonderweg Debate Left Us," German Studies Review 31 (2008): 225-40. 
power of belligerent movements of the far right, followed by their descent into another world war. ${ }^{32}$ But if it was Italy's and Germany's alleged nineteenthcentury deviation from the European norm of political and social development that led to the failure of democracy and the rise of Fascist regimes in both countries, how does the recent historiography approach Italy's and Germany's nineteenth and twentieth centuries?

A number of historians adopt a comparative approach to the study of Italy and Germany in the nineteenth century. ${ }^{33}$ In a short book, Rusconi explores Cavour's and Bismarck's political styles and compares their ideologies and roles in the unification processes. Organized in three separate chapters, two dedicated to Cavour and Bismarck and the third a conclusion, the book is a solid text. It is, of course, legitimate to compare two of the chief protagonists of Italian and German unification with each other and highlight their similarities (such as their privileged backgrounds and their operating in a tension between liberalism and authoritarianism) and differences (Cavour died soon after the establishment of a united Kingdom of Italy and had the broad support of a liberal parliamentary majority; Bismarck remained in charge of German politics for almost two decades after unification and often bypassed parliament). In perhaps the strongest section of the book, Rusconi explores the ambiguous reactions of German intellectuals and officials under Bismarck toward Italian unification, emphasizing, as legions of other historians have done, the European dimension of the Risorgimento (Rusconi, 47-90). ${ }^{34}$ Although the comparison between Bismarck and Cavour soon became part of nationalist discourses, perhaps a more revealing pairing of ItaloGerman political figures of the late nineteenth century who had even more farreaching political contacts with each other were the Iron Chancellor and Francesco Crispi, twice Italian prime minister in the 1880s and 1890s. These two leaders, joined in the Triple Alliance, admired one another's ruthlessness and leadership as they presided over the completion of national unification and soon began to

${ }^{32}$ Few historians still advocate the Sonderweg. For a comparative take, see Knox, To the Threshold of Power, 1922/33; on Gramsci's interpretation, see Selections of the Prison Notebooks of Antonio Gramsci, ed. and trans. Quintin Hoare and Geoffrey Nowell Smith (London, 1971), 44-120; on context, see John A. Davis, ed., Gramsci and Italy's Passive Revolution (London, 1979); for a recent interpretation, see Paul Corner, "The Road to Fascism: An Italian Sonderweg?" Contemporary European History 11 (2002): 273-95; cf. Alexander De Grand, “Comment on Corner: Giolitti's Italy-Sonderweg or WellTravelled Road?" Contemporarv European Historv 11 (2002): 296-300.

${ }^{33}$ For a review of earlier work, see Costanza D'Elia, "The Hidden Comparison: Modern Italy in German Perspectives," Journal of Modern Italian Studies 1 (1996): 432-47.

${ }^{34}$ Especially on German reactions, see Jens Petersen, "Das deutsche politische Italienbild in der Zeit der nationalen Einigung," in Immagini a confronto: Deutsche Italienbilder und italienische Deutschlandbilder, ed. Angelo Ara and Rudolf Lill (Bologna, 1991), 169204. 
pursue imperialist aspirations. A third comparison, that of Bismarck and Garibaldi, both celebrated in official and public memory as "fathers of the nation" from the late nineteenth century onward, is likewise promising. ${ }^{35}$

Nonetheless, Rusconi's book would have undoubtedly benefited from a more systematic exploration of Italy and Germany after unification and a closer engagement with the recent literature on the Risorgimento, which has emphasized the foundations of Italian unification in mass culture and, to a lesser extent, the opposition of many Italians toward unification. To what extent did late unification, the role of the bourgeoisie, and ideas of national expansion prompt the failure of democracy in Italy and the rise of Fascism? The debates about the rivoluzione mancata and the Sonderweg would surely have deserved closer examination here (182-86, 195-200). ${ }^{36}$

A refreshing post-Sonderweg approach toward the history of Italy and Germany in the nineteenth century is Manuel Borutta's 2010 study of anti-Catholicism in nineteenth-century Italy and Germany. Borutta, inspired by Christopher Clark's and Wolfram Kaiser's work on Catholic-secular conflicts in the nineteenth century and by many other existing works on the Kulturkampf and the Roman Question, ${ }^{37}$ explores the nexus among anti-Catholicism, liberalism, and nationalism. He focuses on Piedmont and Prussia, the two states leading the processes of national unification. Borutta argues that anti-Catholicism, with its origins during the Enlightenment, accompanied the national unification processes in Germany and Italy. While this argument hardly surprises, Borutta's comparative approach is fruitful. A few other comparative studies notwithstanding, both the German and Italian historiographies of the long nineteenth centuries were for a long time more or less isolated in their national paradigms, positing the uniqueness of each nation's history. Residual Italo-German stereotypes have also long stood in the way

${ }^{35}$ Heitmann, Das italienische Deutschlandbild, 2:23; On Crispi, see Christopher Duggan, Francesco Crispi, 1818-1901: From Nation to Nationalism (Oxford, 2002); on the Triple Alliance, see Holger Afflerbach, Der Dreibund: Europäische Großmacht- und Allianzpolitik vor dem Ersten Weltkrieg (Vienna, 2002); for a fruitful comparison between Bismarck and Garibaldi, see Robert Gerwarth and Lucy Riall, "Fathers of the Nation? Bismarck, Garibaldi, and the Cult of Memory in Germany and Italy," European Historv Ouarterlv 39 (2009): 388-413.

${ }^{36}$ See, e.g., Lucy Riall, Risorgimento: The History of Italy from Napoleon to Nation State (Basingstoke, 2009); see also Alberto Mario Banti and Paul Ginsborg, eds., Stora d'Italia: Annali 22. Il Risorgimento (Turin, 2007); for a stimulating critique of this cultural approach, chiefly associated with the work of Alberto Banti, see David Laven, "Why Patriots Wrote and What Reactionaries Read: Reflections on Alberto Banti's La nazione del Risorgimento," Nations and Nationalism 15 (2009): 419-26.

${ }^{37}$ Christopher Clark and Wolfram Kaiser, eds., Culture Wars: Secular-Catholic Conflict in Nineteenth-Century Europe (Cambridge, 2003); among the literature on the Kulturkampf, the following work stands out: David Blackbourn, Marpingen: Apparitions of the Virgin Mary in Bismarckian Germany (Oxford, 1993); on the Roman Question, see still Renato Mori, La Questione Romana, 1861-1865 (Florence, 1963). 
of such a comparative approach (Borutta, 394). Borutta also locates the origins of modern secularization theory in this period of confessional struggle, although the theory of secularization has a longer history that goes back to the eighteenth century (Borutta, 267-389). All in all, through his combination of religious, political, and cultural history, Borutta makes a strong case for a comparative history of nineteenth-century Italy and Germany. Since he firmly puts the two countries into a wider European context, his study sets a high standard for future work on Italy and Germany in the long nineteenth century.

The laudable aim of departing from a notion of particularity in favor of comparison guides the 2011 essay collection on the Italian and German nobility in the long nineteenth century edited by Gabriele Clemens, Malte König, and Marco Meriggi. The focus of this volume is the place of the nobility in German and Italian political culture. Not all essays in the volume are comparative, although the most engaging ones, especially Hartwin Spenkuch's comparison between the Prussian Herrenhaus and the Italian Senate, complicate the view of the purported similarity of the two newly united nation-states. In Prussia, the nobility continued to play a significant political role practically until the abolition of the monarchy in 1918. In contrast, in Italy, Giolitti's 1912 electoral reforms undermined the power of the Senate, which consisted of members appointed for life by the king. Spenkuch distills important conclusions from his comparative work that sound vaguely similar to the Sonderweg hypothesis: he sees Italy as a forwardlooking, liberal polity, while Germany seems stuck in a past age, dominated by the Junker who prevented political reforms through their veto power in the Herrenhaus, the upper house of the Prussian parliament (Spenkuch in Clemens, König, Meriggi, 119).

The portrait of a more liberally minded Italy and a reactionary Germany also comes through in a summary sketch by Franz J. Bauer on the question of whether Italy and Germany can be characterized as bourgeois nation-states in the nineteenth century. Bauer's essay is part of a 2006 volume, edited by Christof Dipper, of largely synthetic comparative essays on Italy and Germany in the nineteenth and twentieth centuries. Bauer contends that Imperial Germany's structural problem was the lack of political influence of the bourgeoisie, while Liberal Italy's structural deficit lay in the fact that the political system was almost entirely dominated by bourgeois elites, an unsurprising argument. The effective exclusion from governmental power of large masses of Italians and Germans, despite universal male suffrage in the elections for the Reichstag, stood in sharp tension with the increasing rise of the masses as politicized actors (Bauer in Dipper, 120).

What was the legacy of these nineteenth-century developments for the twentieth century? In an essay in Dipper's volume, Wolfgang Schieder, perhaps the leading German historian of Italo-German relations in the twentieth century, traces the long-term origins of Fascism in Italy and Germany in the decades after national unification using modernization theory. Rather than identifying Fascist 
Italy or Nazi Germany as modernizing regimes, Schieder argues that Fascism and Nazism rose to power because of "cumulative modernisation crises" affecting both countries (Schieder in Dipper, 179). Here were two belated nation-states lacking democratic legitimacy at a time when the masses were progressively demanding the vote. While there was universal male suffrage in the elections for the Reichstag, Schieder also diagnoses a lack of parliamentary democracy in Imperial Germany (Schieder in Dipper, 169). However, recent work has highlighted the significance of the Reichstag elections for the birth of a new democratic culture in Imperial Germany. ${ }^{38}$ Schieder sees some parallels in the political history of late nineteenth-century Italy and Germany that constituted the "prehistory of Fascism and National Socialism" (Schieder in Dipper, 168). As if the Sonderweg approach had not been thoroughly dismantled in the 1980s by British historians, Schieder implicitly still adheres to it. ${ }^{39}$

Despite this conceptual problem, Schieder makes some astute observations on German and Italian politics in the last decades of the nineteenth century. Leo von Caprivi, Bismarck's successor as Reich chancellor, tried to reform the Prussian three-class franchise and brought in a number of welfare policies, such as the ban on Sunday work, to cope with the increasing push of the masses for more political representation. Similar attempts to provide the state with more popular legitimacy while maintaining the status quo also motivated Giovanni Giolitti, prime minister on several occasions from 1892 onward, to push through electoral reforms that extended suffrage to most men. ${ }^{40}$ According to Schieder, both Caprivi and Giolitti tried to pursue a policy of national reconciliation that met vociferous opposition from groups on the right, including the Alldeutscher Verband and the Associazione Nazionalista Italiana, organizations that were not very large in numbers. Despite fervent debates about the real political significance of such groups as the German Navy League, the Pan-German League, or the Italian Nationalist Association, there were undoubtedly some social imperialist strategies at work in both Italy and Germany. ${ }^{41}$ These imperialist voices aimed to divert attention from do-

${ }^{38}$ See Jonathan Sperber, The Kaiser's Voters: Electors and Elections in Imperial Germanv (Cambridge, 1997); Margaret Lavinia Anderson, Practicing Democracy: Elections and Political Culture in Imperial Germany (Princeton, NJ, 2000).

${ }^{39}$ For a stimulating discussion, see Corner, "The Road to Fascism."

${ }^{40}$ On the Giolittean age, see Emilio Gentile, Le origini dell'Italia contemporanea: L'età giolittiana (Bari/Rome, 2003); see also Alexander De Grand, The Hunchback's Tailor: Giovanni Giolitti and Liberal Italy from the Challenge of Mass Politics to the Rise of Fascism, 1882-1922 (Westport, CT, 2001), 61-195.

${ }^{41}$ The classic literature on Social Imperialism is Hans-Ulrich Wehler, Bismarck und der Imperialismus (Cologne, 1969); for a critique, see Geoff Eley, "Defining Social Imperialism: Use and Abuse of an Idea," Social Historv 1 (1976): 265-90, and Eley, Reshaping the German Right: Radical Nationalism and Political Change after Bismarck (New Haven, CT, 1980). 
mestic political and constitutional tensions, above all from the rise of socialism, and tried to rally the masses behind them. In the Italian case, the brutal invasion of Libya in 1911, fifty years after the unification of the nation-state, manifested this tendency (Schieder in Dipper, 171). ${ }^{42}$

Imperialism in the newly united Italian and German nation-states is the subject of an essay by Schieder first published in 1998. In it, Schieder maps out some thoughtful deliberations on imperialism in Italy and Germany, two new nationstates lacking a colonial tradition, and argues that the fatal link between "nationalist mobilisation and foreign policy aggression" in Italy and Germany set imperialism in those countries apart from other manifestations of it, above all in Britain and France, countries with a long colonial tradition. For Schieder, a particularly lethal combination of nationalism and imperialism led the way to Fascism and Nazism. ${ }^{43}$ Schieder balances his argument against the interpretation of the primacy of foreign policy as the chief cause of imperial expansion in the late nineteenth century. He interprets the imperialist policies of Italy and Germany as the result of domestic politics, in line with the "primacy of domestic politics," advocated by leading protagonists of the Sonderweg such as Eckart Kehr and Hans-Ulrich Wehler. ${ }^{44}$ But unlike other historians, Schieder does not blame abstract social processes for imperial expansion. Instead, he argues that particular statesmen and governments were responsible for imperial expansion in Italy and Germany. Here was a new imperialism, domestically inspired to rally the masses behind the nation and to divert social unrest — an imperialism different from that of Bismarck and Crispi that stemmed, according to Schieder, from their belief in the primacy of foreign policy (Schieder in Dipper, 170-71) ${ }^{45}$ Clearly, the nexus between nation-building and empire-building, two processes that coincided with each other, deserves more detailed analysis. ${ }^{46}$

Despite the stimulating perspective on the new imperialism in Italy and Germany, Schieder's teleological argument about a modernization crisis that hit Italy and Germany in the late nineteenth century and after the First World War fails to

42 On the Italian campaign in Libya, see Angelo Del Boca, Gli italiani in Libia: Tripoli bel suol d'amore 1860-1922 (Rome/Bari, 1986).

${ }^{43}$ Wolfgang Schieder, "Imperialismus im unfertigen Nationalstaat: Einige vergleichende Überlegungen zu Deutschland und Italien," in Gestaltungskraft des Politischen: Festschrift für Eberhard Kolb, ed. Wolfram Pyta and Ludwig Richter (Berlin, 1998), 21120; Schieder's essay can also be found in his Faschistische Diktaturen, 341-52; for a similar argument, see Aristotle E. Kallis, "Expansionism in Italy and Germany between Unification and the First World War: On the Ideological and Political Origins of Fascist Expansionism," European Historv Ouarterlv 28 (1998): 435-60.

${ }^{44}$ The classic text here is Eckart Kehr, Der Primat der Innenpolitik: Gesammelte Aufsätze zur preußisch-deutschen Sozialgeschichte im 19. und 20. Jahrhundert, ed. HansUlrich Wehler (Berlin, 1965).

${ }^{45}$ Schieder, Faschistische Diktaturen, 341-52.

${ }^{46}$ For a fruitful perspective, see Jan Rüger, The Great Naval Game: Britain and Germany in the Age of Empire (Cambridge, 2007). 
convince entirely, as it makes the rise of Fascism and Nazism sound almost inevitable. While Schieder admits that economic factors, above all the Great Depression in the German case, helped pave the way for the rise of the Nazis, he devotes little time to short-term factors in the rise of Fascism and Nazism such as the crucial decisions of the king and the Reich president to appoint Mussolini and Hitler to their offices (Schieder in Dipper, 172-76). Furthermore, Schieder ignores the rich and diverse English-speaking literature on Imperial Germany that has effectively questioned the plausibility of the Sonderweg hypothesis. ${ }^{47}$ Moreover, to add to the critique of approaches that prioritize long-term factors in explaining the rise of Fascism, the Weimar Republic was not doomed to failure from the outset; indeed, it lasted for fourteen years despite suffering from heavy political, diplomatic, and socioeconomic challenges, as recent research has emphasized. ${ }^{48}$

A significant problem with work on Italy and Germany in the nineteenth century needs to be raised. If pursued in an exclusively bilateral framework, as most of the titles reviewed here do, then Italy and Germany appear almost inevitably as special cases and deviations from an idealized norm of Western modernization. Italo-German history, pursued in this way, runs the risk of delivering predictable results and making Italy and Germany look more special than they actually were in a European context. It is in the simultaneity of nation- and empire-building where a fruitful comparison between Italy and Germany could be made more systematically, building on the recent rich and diverse work on empire and imperialism. ${ }^{49}$

While Schieder's teleological take on the long-term origins of Fascism and Nazism is unpersuasive, his remarks on the coincidence of nation-building and empire-building in Italy and Germany deserve to be followed up. Perhaps one needs to step back from the view that empire and nation necessarily constituted different categories. In fact, before the First World War, which led to the disintegration of four great European empires - Austro-Hungarian, German, Ottoman, and Russian - most Europeans expected that every successful nation-state would have some overseas colonies. ${ }^{50}$ A good start would be a comparison of imperialist ambitions and policies in the 1880s and 1890s, decades following national

${ }^{47}$ Richard J. Evans, ed., Society and Politics in Wilhelmine Germany (London, 1978); Evans, "Whatever Became of the Sonderweg?" in his Rereading German History 18001996: From Unification to Reunification (London, 1997), 12-22; Eley and Blackbourn, Peculiarities of German History.

${ }^{48}$ On the newer literature on the Weimar Republic, see Benjamin Ziemann, "Weimar Was Weimar: Politics, Culture, and the Emplotment of the Weimar Republic," German Historv 28 (2010): 542-71.

${ }^{49}$ For a survey on Italian Imperialism, see Ruth Ben-Ghiat and Mia Fuller, eds., Italian Colonialism (Basingstoke, 2005); on German Imperialism, see Sebastian Conrad, German Colonialism: A Short History (Cambridge, 2012).

${ }^{50}$ On this point, see Heather Jones, "The German Empire," in Empires at War 19111923, ed. Robert Gerwarth and Erez Manela (Oxford, 2014), 52-72, 57; Jan Rüger, "Sovereignty and Empire in the North Sea, 1807-1918," American Historical Review 119 (2014): 313-38. 
unification and coinciding with the global scramble for Africa, without falling victim to facile explanations that posit a more or less straight line of continuity from pre-1914 colonial atrocities to the Holocaust. ${ }^{51}$

III

Profound work on the relationship between Fascist Italy and Nazi Germany has perhaps been Wolfgang Schieder's most significant contribution. Since the 1970 s - that is, before a more rigorous conceptualization of transnational and transfer history - he has been at the forefront of the study of Fascist-Nazi relations. For Schieder, a highly idealized German perception of the Italian Fascist dictatorship — after all, the first of its kind in the world - helped legitimize the coming of the Third Reich during the Weimar years. Especially powerful for German admirers of Italian Fascism was the myth of Mussolini as a tough, masculine fighter, ostensibly fully integrated into the constitutional framework of the Italian state, along with the monarchy, the army, the bureaucracy, and, from 1929, the Catholic Church. ${ }^{52}$

In a 2013 book, part essay, part source collection, emblematic of a renewed interest in the Mussolini cult, Schieder examines German perceptions of the Mussolini myth through an original perspective: the audiences Mussolini granted to Germans between 1923 and 1943. ${ }^{53}$ These audiences became an essential vehicle of Mussolini's rule, as they reinforced the myth of the Duce as a powerful dictator. In the book's strongest section, Schieder explores the choreography of Mussolini's audiences, taking insights from the recent cultural history of political ceremonies (Schieder, 35-70). ${ }^{54}$ From 1929, the audiences took place in Mussolini's vast office in the sala del mappamondo of the Palazzo Venezia in the center of Rome. If Mussolini wanted to please guests, he would wait for them by the entrance; others had to walk the long distance from the door to Mussolini's desk.

${ }^{51}$ On this approach, see Benjamin Madley, "From Africa to Auschwitz: How German South West Africa Incubated Ideas and Methods Adopted and Developed by the Nazis in Eastern Europe," European Historv Ouarterlv 35 (2005): 429-64; see also Jürgen Zimmerer, "War, Concentration Camps and Genocide in South-West Africa: The First German Genocide," in Genocide in German South-West Africa: The Colonial War of 1904-1908 and Its Aftermath, ed. Zimmerer and Joachim Zeller (Monmouth, 2008), 41-63; for a sharp critique, see Robert Gerwarth and Stephan Malinowski, "Hannah Arendt's Ghosts: Reflections on the Disputable Path from Windhoek to Auschwitz," Central European Historv 42 (2009): 279-300.

${ }_{52}$ A readily accessible guide to Schieder's work is his Faschistische Diktaturen.

${ }^{53}$ See, e.g., The Cult of the Duce: Mussolini and the Italians, ed. Stephen Gundle, Christopher Duggan, and Giuliana Pieri (Manchester, 2013).

${ }^{54}$ For a previous version, see Wolfgang Schieder, "Audienz bei Mussolini: Zur symbolischen Politik faschistischer Diktaturherrschaft 1923-1943," in Italien, Blicke: Neue Perspektiven der italienischen Geschichte des 19. und 20. Jahrhunderts, ed. Petra Terhoeven (Göttingen, 2010), 107-32. 
After the September 1930 breakthrough of the Nazis in the Reichstag elections, Mussolini became more conscious of the importance of influencing the increasing number of Nazi visitors with a positive image of Fascism. Going to Rome became an almost ritualistic journey for Nazi leaders who, despite their ambiguous attitudes toward Italy, continued to cherish Mussolini as their idol. This process helped provide historical legitimacy to the Nazis by pointing to an antecedent to Hitler, perhaps Mussolini's most significant German fan, whose relationship with the Duce requires a more exhaustive investigation. While Schieder, on occasion, gets carried away by his rich material, his book - particularly the appendix with reports of Germans who had been received by the Duce - is an indispensable source for anyone interested in the rapport between Fascist Italy and Nazi Germany. Nevertheless, Schieder's story would have been much more complex if there had been more explicit international context. For instance, the Nazi imitation of Fascist political practices alone did not make an Italo-German alliance inevitable. Here again is the conceptual flaw emblematic of the literature on Italo-German relations: it needs to be placed in a wider European context and cannot exclusively be studied through Italian and German sources. At the same time, however, Schieder's work has opened up a fascinating perspective in which a fruitful conversation about transfers, similarities, and differences becomes possible among historians of Fascist Italy and Nazi Germany, both fields often isolated in their national contexts.

IV

While few of these recent comparative studies succeed fully in unpacking the dynamics of the complex, ambiguous, and dynamic relationship between Italy and Germany, they do offer some insights into national differences and similarities. Despite the great variety of work in this field, there are three broad thematic patterns.

First, the history of national stereotypes has emerged. In fact, a good deal of the literature on Italo-German relations is still overshadowed by national stereotypes. More work remains to be done on how stereotypes have influenced the political and social histories of Italo-German relations. Second, much work grapples with the question of the extent to which the national histories of Italy and Germany were unique. In most of the works under review, the comparative approach takes the formation of the nation in Italy and Germany as a given, a perspective that distorts Italo-German relations in the nineteenth century and makes Italy and Germany look more special and exceptional than they probably were. ${ }^{55}$ This is per-

${ }^{55}$ For a fruitful perspective, see James J. Sheehan, "Paradigm Lost? The 'Sonderweg' Revisited," in Transnationale Geschichte: Themen, Tendenzen und Theorien, ed. Gunilla Budde, Sebastian Conrad, and Oliver Janz (Göttingen, 2006), 150-60. 
haps the greatest lacuna in the work I have discussed here, and it stems from most historians' habit of studying this bilateral relationship almost exclusively from the perspective of Italian and German sources. Such an approach reinforces the view of Italy and Germany as special, exceptional, and outside the norm. But this problem is obviously complex and reflects the problem of recent approaches toward Italo-German history. On the one hand, this field goes beyond nation-state history and therefore constitutes a major step forward for most historians, who have had to become familiar with two languages and two historiographies. Yet, on the other hand, the existing scholarship on this relationship then often focuses too much on the relationship per se without placing it in a broader European context. The question remains how historians can study the bilateral relationship of Italy and Germany in a broader European or global context. One possible approach would be to consider foreign sources, such as French, British, or American diplomatic sources, newspapers, and government papers, and explore how they viewed Italo-German relations. Many historians have adopted this method, including Jens Petersen in his 1973 study of the emergence of the Axis alliance, or Paul Preston in his essay on Mussolini's involvement in the Spanish Civil War. In their 1976 anthology on the Spanish Civil War, Schieder and Dipper also pursued a broader European perspective, so this contextualization of ItaloGerman relations is eminently feasible. ${ }^{56}$ But the fact that so much of the work under review here follows a narrower Italo-German perspective is perhaps emblematic of a misunderstanding of transnational history as a study of transfers and flows from one country to another, without explicitly considering that these exchanges took place in a wider European, if not global, framework.

As the critics of the Sonderweg argued decades ago, the notion of "special" begs for a definition of the "normal" to which it relates, but most of the studies under review here fail explicitly to identify what constituted the "normal" in late nineteenth-century Europe. Still, given the recent reflective and methodological shift toward transnational and transfer history, articulated most forcefully perhaps by Michael Werner's and Bénédicte Zimmermann's plea for a histoire croisée, surprisingly few works reviewed here have taken this approach into account to unpack the dynamics of Italo-German relations. ${ }^{57}$ An unexpectedly original contribution to an Italo-German transfer history, although one that is at times frustratingly impenetrable, is Mauro Fosco Bertola's 2014 study of nationalism in Italian symphonic music discourses and practices from 1890 until 1945. Bertola

${ }^{56}$ See Petersen, Hitler-Mussolini; Paul Preston, "Mussolini's Spanish Adventure: From Limited Risk to War," in The Republic Besieged: Civil War in Spain, 1936-1939, ed. Paul Preston and Ann L. Mackenzie (Edinburgh, 1996), 21-51; Wolfgang Schieder and Christof Dipper, eds., Der Spanische Bürgerkrieg in der internationalen Politik (Munich, 1976).

${ }^{57}$ Michael Werner and Bénédicte Zimmermann, "Beyond Comparison: Histoire Croisée and the Challenge of Reflexivity," Historv and Theorv 45 (2006): 30-50. 
shows how academic and artistic elites adopted Italy's rich musical heritage after Italian unification to craft a distinctly Italian national musical tradition. An important reference point for these elites was what they regarded as the German musical tradition, also largely manufactured and invented in the age of nationalism and above all during the 1930s promotion of cultural exchanges between Fascist Italy and Nazi Germany, especially after the 1938 Italo-German Cultural Treaty, an overture, according to Jens Petersen, to the subsequent Pact of Steel $(25-26,306) .{ }^{58}$ While Bertola mentions Wagner and Verdi, his focus on symphonic music diverts attention from the fact that, despite the intrinsically international nature of opera, music theater was one of the most significant artistic vehicles to create a sense of Italian nationalism. ${ }^{59}$

The third broad pattern of the recent work I have examined in this article still focuses on the 1930s and 1940s, even though historians have attempted to broaden the chronological frame of the history of Italo-German relations. But this emphasis on Fascism and Nazism is hardly surprising given the enormous significance of the Axis alliance before and during the Second World War. Some recent work has analyzed the connections between Fascist Italy and Nazi Germany and has explored some transfers of political ideas and practices between them, examining, for instance, how Fascist colonialism served as a model for Nazi planning of the occupation of Eastern Europe. ${ }^{60}$ While offering rich archivally grounded accounts of transfer processes, many of these studies fail to address the central issue of explanation and causality. To what extent was it Fascist Italy's colonial policies that influenced Nazism's genocidal warfare in Eastern Europe? What about the impact of other imperial powers' colonial practices? More methodological self-reflection is necessary, as is a stronger contextualization and historicization of the changing images of the German and the Italian,

${ }^{58}$ On context, see Jens Petersen, "Vorspiel zu 'Stahlpakt' und Kriegsallianz: Das deutsch-italienische Kulturabkommen vom 23. November 1938," Vierteljahrshefte für Zeitgeschichte 36 (1988): 41-77; Andrea Hoffend, Zwischen Kultur-Achse und Kulturkampf: Die Beziehungen zwischen "Drittem Reich" und faschistischem Italien in den Bereichen Medien, Kunst, Wissenschaft und Rassenfragen (Frankfurt, 1998), 325-55; for an English survey, see Ruth Ben-Ghiat, "Italian Fascists and National Socialists: The Dynamics of an Uneasy Relationship," in Art, Culture and Media under the Third Reich, ed. Richard A. Etlin (Chicago, 2002), 257-84.

${ }^{59}$ See Axel Körner, "Opera and Nation in Nineteenth-Century Italy: Conceptual and Methodological Approaches," Journal of Modern Italian Studies 17 (2012): 393-99.

${ }^{60}$ For a review of some of this work, see Christian Goeschel, "Italia Docet? The Relationship between Italian Fascism and Nazism Revisited," European Historv Ouarterlv 42 (2012): 480-92; see, among others, Sven Reichardt and Armin Nolzen, eds., Faschismus in Italien und Deutschland: Studien zu Transfer und Vergleich (Göttingen, 2005); Patrick Bernhard, "Borrowing from Mussolini: Nazi Germany's Colonial Aspirations in the Shadow of Italian Expansionism," Journal of Imperial and Commonwealth Historv 41 (2013): 617-43; Thomas Schlemmer and Hans Woller, eds., Der Faschismus in Europa: Wege der Forschung (Munich: Oldenbourg, 2014). 


\section{Goeschel}

overshadowed, to varying degrees at different times, by the ambiguous nature of Italo-German relations. These relations were characterized by a historically conditioned and dynamic combination of exchange and animosity, love and hatred, admiration and contempt. The question is thus, to go back to Croce, not only how Italy played the "part of the teacher in politics" of Germany in the nineteenth and twentieth centuries, during unification and the rise of Fascism, but also how cultural stereotypes transformed these transfer processes. This insight suggests that historians should pay more attention to how national stereotypes are being constructed, and how these images pervade political discourses. ${ }^{61}$ These considerations seem especially relevant at a time when an economically and politically stagnant Italy is becoming increasingly marginalized in European politics and is portrayed by some as the "sick man of Europe." ${ }^{2}$ A more intellectually reflective exchange between historians of Italy and Germany, discussing insufficiently explored subjects such as empire, may lead to a reconsideration of Fischer's view of Italy as a place of political experimentation and innovation that played a central role in European history.

${ }^{61}$ For an example, see Patriarca, Italian Vices.

${ }^{62}$ See Andrea Mammone and Giuseppe A. Veltri, eds., Italy Today: The Sick Man of Europe (London, 2010). 